Session TC2-1

\title{
Donor Relationships are the Key to Development Activities that Can Provide your Engineering or Engineering Technology Program Its Margin of Excellence.
}

\author{
Walter W. Buchanan \\ Department of Engineering Technology and Industrial Distribution \\ Texas A\&M University \\ Alireza Rahrooh \\ Department of Engineering Technology \\ University of Central Florida \\ Kudret Yurtseven \\ Department of Industrial Engineering \\ Yeditepe University
}

\begin{abstract}
Public institutions are getting less of their budgets from their state legislatures in recent times. To find a solution to this problem programs at state institutions have been forced to get funding from alternate sources. This can mean grants from federal or private sources, royalties from patents obtained by the faculty, and gifts from philanthropic foundations. Engineering and engineering technology programs have another source. Due to their close contacts with industry, these departments can work with their industrial supporters to obtain funding from them, both equipment and cash donations. These departments also have many alumni at technical companies, who are very loyal to their alma maters. These alumni are very receptive to appeals from the departments from which they obtained their education, to help these departments in increasing the quality of their programs. In fact, it is more than loyalty that motivates these alumni. If the program from which they came increases in quality and status, this can only result in increasing the value to the alumni's degrees. This paper will show the importance of networking and building relationships to further development activities in an engineering technology department at public institution, so that the department can increase in quality for future graduates. One method that works very well at Texas A\&M University is to take prospects and donors to football games! This paper will show the results of what this process can bring about.
\end{abstract}

\section{Introduction}

Over the years the authors have found that industrial advisory boards can serve many useful functions. The obvious one is providing input to an engineering technology or engineering program on what they can do to make their curriculum more responsive to the needs of industry. Another important function is aiding the department in obtaining free or discounted equipment for laboratories and even cash donations. The later function will be the focus of this paper. [1] 
When one of the authors arrived at Texas A\&M University, he was impressed with the strength of the department's industrial advisory committees. In fact there were three separate committees: one for electronics and telecommunications engineering technology, one for manufacturing and mechanical engineering technology, and one for industrial distribution. Each committee focused on their area and all were effective in curriculum advising and equipment donations. [2] It was decided to combine the development functions into one group and create a departmental development to concentrate purely on fundraising. It was felt that synergies would result from the combination. [3] Although this turned out to be the case, after a couple of years the department decided to create separate development groups for each program, so they could focus on their own particular needs. One really good result of the departmental development council, however, was that solid relationships were developed with industrial advisory committee members that resulted in significant fundraising. [4]

\section{Supporter Relationships}

While the departmental development council was in existence, over sixty visits were made to industrial sites where industrial council members were employed. These included visits all over east Texas with many trips made to Houston, Dallas, and Austin, since these areas encompass the majority of the population of the state. A broad range of industries were visited including manufacturing companies, electronics companies, and industrial distribution companies. If after the initial visit, it seemed that there was potential for development purposes, return visits were made. Not only did these visits allow the department head to see what was going on at the particular company, but he was able to develop relationships with the given industrial committee member, who was employed there, in addition to other employees of the company.

These relationships were strengthened by inviting these individuals to Aggie football games. This allowed the department head to first take company and industrial committee members to the presidential buffet before the game and then, of course, to the game itself. Over the course of four football seasons, seventy-five visitors were taken to games, some more than once if development potential was detected. The amount of time spent with the people involved allowed the department head to get to know them quite well and have extended conversations with them. The fundraising results from developing these relationships turned out to be significant and resulted in some very major gifts as will be discussed below. It should be mentioned that about one-fifth of the visits resulted in a donation of some kind.

\section{Results of Relationships with Supporters}

Due to the relationships built with supporters, the Engineering Technology and Industrial Distribution Department at Texas A\&M University has garnered well over two million dollars in gifts in less than three years. The most major examples are a million dollar endowed and fully equipped fluids power laboratory and a one-half million endowed and fully equipped fluid systems laboratory. The result of this is that the manufacturing and mechanical engineering technology programs have state-of-the-art laboratories for the courses taught in these areas.

Other important examples are numerous scholarships and faculty fellowships to aid both students and faculty in the department. One faculty fellowship was endowed for $\$ 100,000$, which will

Proceedings of the 2009 ASEE Gulf-Southwest Annual Conference Baylor University

Copyright $\Subset$ 2009, American Society for Engineering Education 
allow the faculty member recipient to have five-thousand dollars a year in funding to support research and other scholarly activities. Also, in addition to cash donations, significant equipment donations were made that allowed several laboratories to be fully equipped as well as adding equipment to many other laboratories. In fact, within the Dwight Look College of Engineering, which consists of twelve departments, the Engineering Technology and Industrial Distribution Department ranks third in development over the past five years.

\section{Summary and Conclusions}

It is evident from the example above that development efforts in an academic department can greatly enhance the quality of the programs in a department and make possible course offerings that would not be possible with an otherwise limited budget. In our current economy, there is no reason to believe that the percentage of state funding to public institutions is going to increase. Therefore, other efforts are necessary to garner to resources necessary to have quality programs. Development, which can result from developing relationships with departmental supporters, is certainly one important way to achieve this quality.

Development is hard work, however. Considerable time must be spent in development activities for really successful results to be obtained. The lead author recommends that a department head should spend one day a week on visits to prospects and potential donors and then work to develop a long lasting relationship. This includes little things like sending greeting cards each year and inviting the prospect or donor to any event that provides an opportunity for contact. Inviting donors to be a member of your industrial advisory committee is a good idea also if that person can also give meaningful advice to advance the program in question. Data mining is also a useful activity. A good development office can assist the department in obtaining information on which of the program's alumni have sufficient wealth to aid the program. It is vital though that the prospect in question be made to feel part of the program's mission. Providing information on what the program is doing in important to achieve this and therefore a frequent departmental newsletter send to all alumni and supporters of the program is a good idea. This can be done very economically using electronic means. The bottom line here is to make the donor a member of your team.

\section{References}

1. Buchanan, W.W., and Tapper, J., “Optimizing the Industrial Advisory Board Interaction,” Abstracts 2001 ASEE New England Section Conference, Roger Williams University, Bristol, Rhode Island, April 2001, p. 8-9.

2. Buchanan, W.W., Tapper, J., and Rahrooh, A., "Using an Industrial Advisory Council as a Development Council for Obtaining Resources for Engineering Technology Programs,” Proceedings 2006 ASEE Gulf-Southwest Section Conference, Southern University and A\&M College, Baton Rouge, Louisiana, April 2006, pp. 611-614.

3. Buchanan, W.W., Tapper, J., and Rahrooh, A., “The Advantage of Creating a Departmental Development Council to Achieve a Margin of Excellence in an Engineering Technology Department at a Public Institution,” Proceedings 2007 ASEE Gulf-Southwest Section Conference, University of TexasPan American, South Padre Island, Texas, March 2007, pp. T2A11-T2A13.

4. Buchanan, W.W., Tapper, J., and Rahrooh, A., "The Importance of Networking and Building Relationships to Further Development Activities in an Engineering Technology Department at a Public Institution,” Proceedings 2008 ASEE Gulf-Southwest Section Conference, University of New Mexico, Albuquerque, New Mexico, March 2008, pp. 1601-1603.

Proceedings of the 2009 ASEE Gulf-Southwest Annual Conference Baylor University

Copyright $\Subset$ 2009, American Society for Engineering Education 
WALTER W. BUCHANAN

Dr. Buchanan is J. R. Thompson Endowed Chair Professor and Head of the Department of Engineering Technology and Industrial Distribution at Texas A\&M University. He received his BSE and MSE from Purdue University, and his Ph.D. and J.D. from Indiana University. Walt is a P.E. in six states, and is Past Chair of the Engineering Technology Council of ASEE. He has written over 100 papers on engineering technology education, and is a member of the Board of Directors of NSPE.

\section{ALIREZA RAHROOH}

Dr. Rahrooh is Professor of Electrical Engineering Technology and Assistant Chair of Engineering Technology at University of Central Florida. He received his BSEE, MSEE and Ph.D. from University of Akron. He has

numerous publications in various reputable journals and conference proceedings. Ali is a member of the IEEE and ASEE.

\section{KUDRET YURTSEVEN}

Dr. Yurtseven is Associate Professor of Electrical Engineering in the Department of Industrial Engineering at Yeditepe University in Istanbul, Turkey. He is a member of ASEE and IEEE and has written numerous papers in the area of controls and systems engineering. 